\title{
A Review of Research on Creative Teachers in Higher Education
}

\author{
Afida Ayob ${ }^{1}$, Aini Hussain ${ }^{1} \&$ Rosadah Abdul Majid ${ }^{2}$ \\ ${ }^{1}$ Centre for Engineering Education Research and Department of Electrical, Electronics and Systems Engineering, \\ Faculty of Engineering and Built Environment, Universiti Kebangsaan Malaysia, Selangor, Malaysia \\ ${ }^{2}$ Faculty of Education, Universiti Kebangsaan Malaysia, Selangor, Malaysia \\ Correspondence: Afida Ayob, School of Electrical, Electronics \& Systems Engineering, Faculty of Engineering \\ and Built Environment, Universiti Kebangsaan Malaysia, 43600 UKM Bangi, Selangor, Malaysia. Tel: \\ 60-389-118-404. E-mail: afida.ukm@gmail.com
}

Received: February 7, 2013 Accepted: March 20, 2012 Online Published: May 13, 2013

doi:10.5539/ies.v6n6p8

URL: http://dx.doi.org/10.5539/ies.v6n6p8

\begin{abstract}
Effective instructors often have a creative nature. However, the assessment of creative instructors is something that is very rarely seen in the literature of creativity in Malaysia. In fact, in education, there is little information on the practice of creative instructors. However, there are benefits to study creative instructors: in education, it can describe ways to enhance creativity and enrich teaching practices, and in psychology, it can increase our understanding of the social and interpersonal creativity, and creativity in daily practice. This paper reviews research on creative instructors which was conducted throughout the world.
\end{abstract}

Keywords: creativity, creative instructors, effective teaching

\section{Introduction}

Research on creativity is very broad, and encompasses many areas. However, a literature review of research on creativity is very difficult due to the various terms used to describe creativity. For example, in the economic environment, the words 'entrepreneurship' and 'enterprises' are often used, whereas, in sociology, the term used is 'innovation'. In education and psychology, the term 'creativity' also is widely used but the meaning may vary. The word creative is used to describe a teacher, a student, a process, or a product. Davis and Rimm (2004) proposed that creative students outperformed high IQ students in lifetime achievement. However, Gagne (2003) suggested that many factors are responsible in the development of eminent people in a society. Those factors include both the physical environment and the psychological environment which are being referred to as developmental catalysts.

\subsection{Meaning of the Term 'Creativity'}

The concept of creativity is very difficult to determine. Most of the leading authors in the field of creativity have identified a range of activities deemed to be creative; including research that focuses on people who are deemed to be creative such as politicians, scientists, artists and teachers. Some analysts in creativity made a significant distinction in the definition of creativity by differentiating between high level of creativity and common creativity. Another distinction is between creativity in certain domains compared to creativity as a separate process but applied in a particular domain. The description of creativity that will be given further in this paper are included using this second sense.

Most of the research on creativity in the early stages is influenced by the thought of Torrance (1969), who greatly influenced the psychometric approach to creativity in the United States and around the world. Torrance views creativity as a whole as a process of identifying problems, finding possible solutions, making hypotheses, evaluating and communicating the results. Torrance also adds that this process includes the creation of original ideas, diversity of views, out of habits, the combination of new ideas and looking at relationships between ideas. Although the ideas of Torrance are influential and still seen as worth up to the present, his reasoning is still bounded within psychometric approach and receives great criticism and deemed to be outdated.

Webster (1990) in his published work in the area of music education said that the word 'creativity' has lost much of its meaning and power since it has been used in so many different contexts. In the educational context, 
especially in the field of music, he suggested using the term 'cre-ative thinking' because by doing so, emphasis is put on the process and its role in music teaching and learning.

Latest creativity concepts (circa 2000) categorise creativity as high creativity as normal creativity.

\subsection{High Creativity}

A few influential schools of thought regarding the definition of high creativity include:

- 'capacity which is out of expectation for a person in his thinking and creation' (Ryhammar \& Brolin, 1999)

- 'capacity for someone to produce a new and original idea, thought, reorganisation, creation or objects of art, that is accepted by experts as having scientific, aesthetic, social or technological values' (Vernon, 1989)

- $\quad$ 'the capability to produce new knowledge' (Dacey \& Lennon, 2000)

High creativity also covers a wider definition in terms of production of new ideas. However, these definitions only gives exclusive meaning that creativity is only owned by a certain talented individuals, but might be less relevant when discussing student creativity.

\subsection{Normal Creativity or 'Democratic' Creativity}

In the field of education, the definition of normal creativity or 'democratic' creativity might be more suitable. In the report by the National Advisory Committee on Creative and Cultural Education NACCCE (1999) this phrase emerges and brings about the meaning of creativity for normal individuals, with consideration that all students can be creative.

This definition of creativity assumes that creativity can be owned by all students. Among the creativity definitions under this thought are:

- 'Imaginative creativity that is moulded to produced something that is valuable and original' (NACCE, 1999)

- 'Creativity is the application of knowledge and skills to produce a new method to achieve a certain outcome. Therefore a student has to have four quality criteria which are:

- ability to identify new problems, and not depend on others,

- ability to transfer knowledge that they obtained from a certain context to another in solving problems,

○ belief that learning is a multilevel process, where repetition will produce success,

- capacity to focus in achieving an outcome.' (Seltzer \& Bentley, 1999)

However, these definitions would create problems, since there is the deterioration between the normal creativity and others having the same but different adjustment.

\section{Distinction between Creative Teaching and Teaching for Creativity}

It is quite difficult to give distinction between creative teaching and teaching for creativity. According to Cremin (2009), distinction between the two is teacher oriented for the former, and learner orientation for the latter. Creative teaching involves teachers to make learning in class more interesting and informative using imaginative approaches. Teaching for creativity involves teachers identifying and fostering children's creativity.

The National Advisory Committee on Creative and Cultural Education (NACCE, 1999) defines creative teaching as 'teachers using imaginative approaches to make learning more interesting, exciting and effective' and teaching for creativity as 'forms of teaching that are intended to develop young people's own creative thinking or behavior'. Teaching for creativity cannot be achieved without creative teaching.

\section{Creative Teaching}

A teaching is said to be creative when an instructor combines the existing knowledge with a new way that is new or unique or introduces a new process to nourish cognition to obtain a useful outcome (learning). This could be planned before teaching or is adopted as a response towards the needs of a certain learning context.

Creative teaching is an art (Craft, 2001) and therefore instructors cannot be taught didactically on how to be creative. However, instructors need to develop a range of skills themselves which they can adapt and apply to different situations. Davis and Rimm (2004) acknowledged that personal creativity can be enhanced, and they proposed that creativity could be taught. Thus, teachers' creativity in teaching can be trained

In Northern America, most of the thoughts in creativity emerge as a result of case studies of famous inventors in arts and sciences (Csikszentmihalyi, 1996; Gardner, 1993). However, an instructor seldom achieves this level, 
although they are involved with creativity everyday (Rejskind, 2000). Jeffrey \& Craft (2006) and Woods (1995) found that creative instructors are:

- innovative (goes beyond the traditional border through a new combination whether planned or in connection to any benefit);

- have ownership of the knowledge (to modify or customize the curriculum to address the special needs of students and/or educational goals);

- control the teaching processes involved (have the need for choice and the power to make it happen through practical involvement);

- and operates in various social values that are acceptable and at the same time adapted to the culture of the students.

In general, creative instructors are more inclined to (Woods \& Jeffrey, 1996):

- be independent (having own thoughts but capable of working together with others);

- have a humanistic approach (focusing on student self-development);

- guided by a strong moral purpose;

- indicate indecision for equities;

- be learner-centred (creating an atmosphere that ensures student learning and involvement);

- $\quad$ use full control but with full care;

- be very enthusiastic about work.

Other than that, they are involved with and encouraged:

- $\quad$ reasoning based of possibilities, raising questions that help in exploring problems (Jefferey \& Craft, 2006);

- promote student inclusiveness that the instructor is open to hear students' perspectives in learning, and considers students views and ideas seriously (Craft, 2008).

The NACCE (1999) report also highlighted some characteristics of creative instructors. One of the criteria is creative instructors constantly reinvent themselves and adapt their teaching styles and strategies to different situations as required. To achieve this instructors have to have a firm rooting in their identity and principles, and then based on this, be flexible in what they do.

Creative instructors are also risk takers who may have to leave the structured lessons behind and adjust them accordingly (Ireson et al, 1999). These instructors are ready to learn from their students and not be afraid of looking foolish. To promote creativity in the students, creative instructors often explore their own creative talents both in teaching and in other area of interests. NACCE (1999) also said that if creativity of instructors is suppressed, they cannot promote creativity in their students.

In general, personality traits, values and teaching positions is synthesized in the form of creative teaching that includes the provisions of curriculum, teaching methods, relationships with students, the creation of the environment and reflection on practice.

\section{Creativity and Learning}

Creative instructors are needed to enhance students creativity and to implement modern curriculum more effectively (inist re de l' ducation, du Loisir et du Sport, 2001; NACCE 1999; Pedagogical Institute, 2003). Creativity is considered an important skill of all students (Sawyer, 2004; Strom \& Strom, 2002), and should be given the same status as literacy (Robinson, 2006). Although creative instructors play an important role in developing students' creativity (Runco, 2006) and creativity is seen as an important dimension in education, there is little research on creative teaching practices. Furthermore, the instructor creativity is required so that a more effective strategy can be formulated in line with current thinking about learning. The paradigm shift on student-centered constructivism requires the instructor to modify the curriculum to meet the interests and needs of individual students, and meet the needs of the growing media hungry for information. However, the guidelines for its implementation in the classroom are less widespread (Windschitl, 2002).

If students need to be creative and be able to develop knowledge, then instructors must be creative to facilitate the process. Although there are answer scripts, the instructor must be able to improve the response in order to answer questions that are not in the script. In that case, creative instructors are indeed very necessary. 


\section{Research on Creative Instructors/ Teachers}

Research on creative teaching has not been widely done though many researchers recognize the importance of creative teaching in the construction of creativity. A few of these will be highlighted here describing the major findings of each study.

\subsection{Creative Teaching and Impact on Students and Colleagues}

A study was conducted by Reilly et al (2011) in Canada for ten years to identify creative teaching and its impact on students and colleagues. This study is based on the concept that creative instructors understand that a class is part of the system in a school, in a district, under the inclusion of a larger community. Creative instructors understand that each student is an open learning system consisting of physical, cognitive and socio-emotional development in a culture that may or may not be conducive to the educational environment. Creative instructors should be aware of this fact and then reflect on their teaching.

This research takes the case study of teachers who have been nominated or have received awards for excellence in teaching or in the innovative teaching methods. This includes individuals who are involved in creative activities and initiatives such as the introduction of teaching or engaging in action research to improve their teaching practices, and creating a living educational theory. The instructors were from primary, secondary, and university levels.

Research on creative teaching is more of qualitative nature. Concepts of creative teaching characteristics were collected and classified according to specific categories although expression of each individual is different. From the results of his analysis to the case study, Reilly found four themes: Creative Process, Creative Individuals, Revenue and Community. However, this paper only discusses the two themes which are Creative Individuals and Communities as both have major implications in teacher preparation and professional development.

As a creative individual, Reilly found that the instructors will have three characteristics, namely, individual intelligence, motivation and other characteristics. Intelligence means that individual teachers understand his own intentions, feelings, emotions and are ready to use these in life, work and relationships. The instructors also have the internal motivation that their careers are very fun and interesting. This is the result of positive values in them. Other feature that they have is not afraid to take risks as long as within the safety bounds of their environment.

The study also found that creative instructors realize that their creativity is influenced by the community in which they live. In many situations, the community is seen as an avenue for creative activities. For example, an instructor uses advanced technology in his teaching as a result of the phrase 'Technology is Vast' that are widely displayed on the school notice boards.

\subsection{Perception of Teachers about Creativity}

Morais (2011) did a study on the perception of instructors about creativity. This study showed that by understanding the perceptions of instructors about the meaning of creativity can help produce practical methods to foster creativity in the classroom.

According to Morais, creative teaching is one that encourages appropriate risk and unexpected situations, and always tries to improve student creativity. Close relationships with students and classroom environment that promotes learning should move in tandem with instructors' background and his ability to enhance the students' cognitive level.

The study found that the instructors' perceptions of teaching and creative teaching are not much different from the concepts that have been defined in theory. By doing the intervention process, which helps isntructors to apply their conception of creative activities, will ensure success in making instructors more able to assess and foster creativity among students. This intervention can be performed through case studies, observations in the classroom, planning and evaluation through the creation of a creative assignment in class.

\subsection{Factors that Influence Creative Teaching and Effective Strategies}

Another study was conducted among creative instructors (Horng, 2005) to look at the factors that influence creative teaching and effective strategies used among three instructors who received awards for creative instructions. All three instructors were subjected to individual in-depth interviews, focus group interviews, classroom observations as well as teaching content analysis.

The study found that factors influencing creative teaching are:

- personality traits (such as self-confidence, perseverance, desire to learn, humour, openness to experience, fantasy oriented, imagination, emotional sensitivity, drive and ambition, norm doubting, nonconformity, attraction to complexity, aesthetic orientation, flexibility of thoughts and risk taking), 
- family backgrounds ( i. family socio-economic status, structure and composition, ii. parents education beliefs relation and expectations with children, and iii. relations among siblings),

- growing up and learning experiences (such as exposure to nature, brainstorming sessions with classmates),

- peer interaction (this includes personal and professional relationships with peers), common beliefs in education (which are self-expression, sharing and communication),

- devotion to creative instructions (developing ideas, designing curricula, arranging activities, revising teaching plans, preparing materials and reflecting on their performance and the students' feedback),

- motivations (dedication to students leading to adoption of interesting lesson plans to create an enjoyable learning environment; love for students; perception that teaching is interesting, involving, satisfying, enjoyable and a personal challenge; competitions and awards not perceived as major goals),

- $\quad$ organisational environment (teamwork is emphasized, networking encouraged, opportunity to contribute and experiment with new ideas, open discussion within the organisation).

The study also recommended some strategies for creative teaching. Firstly, is to use student-centred learning where the instructors become the facilitators for students to develop independent thinking as well as imagination and creativity. Secondly, is to use multi-teaching aids to assist instructions. These aids are used to excite student thinking, broaden their viewpoint and encourage further discussion. Lessons become more interesting, interactive and easier to remember. With the use of computers, students also are provided access to abundant education resources in the internet. Thirdly, is the use of effective classroom management by providing friendly interactions and recognising the individuality and needs of each student. Fourthly, students are allowed to connect teaching contents with real life experiences. This is useful since students will learn how to interact with people, how to handle relationships and unexpected challenges. Finally, is by the use of open-ended questions to encourage imagination and thinking.

According to Horng (2005), developing creative instructors should begin with their training. These instructors should be equipped with the knowledge and skills of giving creative instructions. Schools, colleges and institutions of higher learning should hold workshops of creative instructions, by inviting creative instructors and professionals to share their experiences in developing creativity and improving teaching strategies.

\subsection{Creative Instructors and the Teaching Curriculum}

A qualitative study by Woods (1995) was carried out among primary school teachers through in-class and school observations, interviews, and review of documents, movies and life history of teachers. One of his objectives was to look at effects on teaching curriculum and creativity. He found that frequent changes in teaching contents will stunt teacher creativity as instructors felt they are being forced to adopt certain teaching approaches. So the school administrators should address changes in the learning contents wisely so that instructors continue to have passion to teach creatively

\section{5 'What Makes a Teacher Creative?'}

In one research, Gowan and Bruch (1967) said that it takes more than a creative person to make an effectively creative teacher. Their experiment was conducted during a creativity workshop which involved 350 gifted children in 13 classes, 13 demonstration teachers especially selected for their creative ability, 13 counselors for each class, and 66 trainees. All of the demonstration teachers and the trainees were asked to describe themselves, while the counselors describe the criteria of creative teachers. A list of positive and negative adjectives was constructed. And it was found that these positive adjectives were those used to describe effectively creative teachers. Apart from being a creative person, the teacher or instructor has to have a great deal of energy, self-confidence, daring, a warm outgoing nature (free of immature negativisms), intelligent, original, free of hasty and impatient behaviour.

\subsection{Creative Teacher Initial Training}

Grainger et al (2004) conducted a study on the training of creative teachers. They found that for trainee teachers to adopt creative approaches in teaching, they need to observe tutors teaching creatively and take part in creative learning experiences. Teachers need more than a working knowledge of the curriculum. Teacher trainees has to belief in the potential of creative teaching to engage and inspire hearts and minds, and this will depend on the real-life human interaction between teacher and student. This work suggests that creative teachers use their own creativity to interest and engage learners, resulting in promotion of new thinking and learning. Such teacher will use range of approaches to create conditions to flourish creativity of others. 


\subsection{Questions Asked by Creative Teachers}

In a study by Torrance and Hansen (1965), they compared between question-asking behaviors between six highly creative and six less creative instructors. These instructors were classified based on the results of a written test on creative thinking abilities. Detailed classroom observations were made to identify the sort of questions being asked in class. Using a scoring system, each question was assigned a score. A heavier score weight is assigned if the question involve divergent responses (deviation from basics) and are self-involving (make use of 'you' and rely upon personal experience, perception, opinion or thought for an answer). Less score weight is given for simple answer question and factual questions. Results found that the mean score for highly creative instructors were 22 times larger than the less creative ones. This proves that highly creative instructors asked markedly different questions than their less creative counterparts.

\section{Conclusion}

There are various researches in creative instructors, some of which focuses on the people's perception of creative instructors resulting in a long list of traits that instructors should possess. Another research focuses on making close observations and analysis of creative teachers resulting in accounts of individual practices.

Creative instructors are not only necessary to achieve the complex educational goals, but they are also necessary to inculcate skills of the students so that they can act more effectively in today's globalized world. Of the studies that have been conducted around the world, creative teachers share many similar characteristics, such as student-centered, fostering students' interest in the classroom, showing a high awareness and interpersonal skills, have internal motivation that is based on values, and willing to take risks while still within the compounds of their safe environment.

Research on creative teaching should be done in Malaysia to evaluate whether the instructors in Malaysia have creative elements in themselves and then can be translated in teaching in the classroom. With this, more creative students will be produced and thus can subsequently achieve the national goal to increase innovation.

\section{Acknowledgements}

This work has been funded by the Action Research Grant of the National University of Malaysia under the Engineering Education Research Center, Faculty of Engineering and Built Environment.

\section{References}

Craft, A. (2008). Creativity and early year's settings. In A. Paige-Smith, \& A. Craft (Eds.), Developing reflective practice in the early years (pp. 93-107). New York: Open University Press.

Craft, A., Jeffrey, B., \& Leibling, M. (2001). Creativity in Education. Continuum International Publishing Group.

Cremin, T. (2009). Creative teachers and Creative Teaching. In Wilson, A. (Ed.), Creativity in Primary Education. SAGE Publications.

Csikszentmihalyi, M. (1996). Creativity. New York: HarperCollins.

Dacey, J., \& Lennon, K. (2000). Understanding creativity: The interplay of biological, psychological and social factors. Creative Education Foundation, Buffalo, NY.

Davis, G. A., \& Rimm, S. B. (2004). Education of the gifted and talented (5th ed.). Allyn \& Bacon: Boston.

Gagne, F. (2003). Transforming gifts into talents: The DMGT as a developmental theory. In N. Colangelo, \& G. A. Davis (Eds.), Handbook of gifted education (3rd Ed). Boston: Allyn and Bacon.

Gardner, H. (1993). Creating minds. New York: Basic Books.

Gowan, J. C., \& Bruch, C. (1967). What Makes a Creative Person a Creative Teacher? Gifted Child Quarterly, $11,157$.

Grainger, T., Barnes, J., \& Scoffham, S. (2004). A creative cocktail: Creative teaching in initial teacher education. Journal of Education for Teaching: International Research and Pedagogy, 30(3), 243-253. http://dx.doi.org/10.1080/0260747042000309475

Horng, J. S., Hong, J. C., ChanLin, L. J., Chang, S. H., \& Chu, H. C. (2005). Creative teachers and creative teaching strategies. International Journal of Consumer Studies, 29, 352-358. http://dx.doi.org/10.1111/j.1470-6431.2005.00445.x 
Ireson, J., Mortimore, P., \& Hallam, S. (1999). The common strands of pedagogy and their implications. In Martimore, P. (Ed.), Understanding pedagogy and Its Impact on Learning. London: Paul Chapman. http://dx.doi.org/10.4135/9781446219454.n11

Jeffrey, B., \& Craft, A. (2006). Creative learning and possibility thinking. In B. Jeffrey (Ed.), Creative learning practices (pp 47-62). London: Tufnell Press.

Minist re de l' ducation, du Loisir et du Sport. (2001). Quebec education program: preschool and elementary. Retrieved

from http://www.mels.gouv.qc.ca/DGFJ/dp/programme_de_formation/primaire/educprg2001h.htm

Morais, M. F., \& Azevedo, I. (2011). What is a creative teacher and what is a creative pupil? Perceptions of

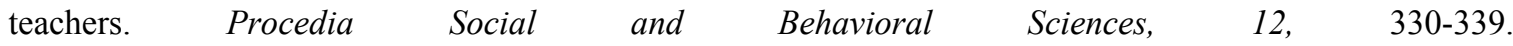
http://dx.doi.org/10.1016/j.sbspro.2011.02.042

National Advisory Committee on Creative and Cultural Education (NACCCE). (1999). All our futures: Creativity, culture and education. Department for Education and Employment, London.

Pedagogical Institute. (2003). A cross thematic curriculum framework for compulsory education. Retrieved from http://www.pi-schools.gr/programs/depps/index_eng.php

Reilly, R. C., Lilly, F., Bramwell, G., \& Kronish, N. (2011). A synthesis of research concerning creative teachers in a Canadian context. Teaching and Teacher Education, 27, 533-542. http://dx.doi.org/10.1016/j.tate.2010.10.007

Rejskind, F. G. (2000). TAG Teachers: Only the creative need apply. Roeper Review, 22, 153-157. http://dx.doi.org/10.1080/02783190009554023

Robinson, K. (2006, February). Do schools kill creativity? (video). Retrieved December 15, 2007, from http://www.ted.com/index.php/talks/view/id/66

Runco, M. (2006). Creativity theories and themes. New York: Elsevier.

Ryhammar, L., \& Brolin, C. (1999). Creativity research: Historical considerations and main lines of development. Scandinavian Journal of Educational Research, 43(3), 259-273. http://dx.doi.org/10.1080/0031383990430303

Sawyer, R. (2004). Creative teaching: Collaborative discussion as disciplined improvisation. Educational Researcher, 33(2), 12-20. http://dx.doi.org/10.3102/0013189X033002012

Seltzer, K., \& Bentley, T. (1999). The creative age: Knowledge and skills for the new economy. Demos, London.

Strom, R., \& Strom, P. (2002). Changing the rules: Education for creative thinking. Journal of Creative Behavior, 36, 183-200. http://dx.doi.org/10.3102/0013189X033002012

Torrance, E. P., \& Hansen, E. (1965). The question asking behaviour of highly creative and less creative basic business teachers identified by pencil-and-paper test. Psychological reports, 17, 815-818. http://dx.doi.org/10.2466/pr0.1965.17.3.815

Torrance, E. P. (1969). Creativity: What research says to the teacher. Series no.28, National Education Association, Washington, DC.

Vernon, P. E. (1989). The nature-nurture problem in creativity. In J. A. Glover, R. R. Ronning, \& C. R. Reynolds (Eds), Handbook of creativity: Perspectives on individual differences. Plenum Press, New York, NY. http://dx.doi.org/10.1007/978-1-4757-5356-1_5

Webster, P. R. (1990). Creativity as Creative Thinking. Music Educators Journal, 76(9). Special Focus: Creative Thinking in Music (May, 1990), pp. 22-28.

Windschitl, M. (2002). Framing constructivism in practice as the negotiation of dilemmas: An analysis of the conceptual, pedagogical, cultural, and political challenges facing teachers. Review of Educational Research, 72, 131-175. http://dx.doi.org/10.3102/00346543072002131

Woods, P. (1995). Creative teachers in primary schools. Buckingham, UK: Open University Press.

Woods, P., \& Jeffrey, B. (1996). Teachable moments. Philadelphia: Open University Press. 